DOI: http://dx.doi.org/10.22201/iie.18703062e.2009.94.2286

\author{
DEBORAH DOROTINSKY ALPERSTEIN
}

INSTITUTO DE INVESTIGACIONES ESTÉTICAS, UNAM

\title{
Imagen e imaginarios sociales Los indios yaqui en la revista Hoy en 1939
}

$\mathrm{E}$ N los Últimos CinCo años la historia de la fotografía en México se ha convertido en un campo sumamente prolífico. En las investigaciones se han rescatado las imágenes fotográficas que desde el siglo XIX constituyen parte de nuestro caudal histórico fotográfico. Me refiero aquí a la producción fotográfica que ha sido abordada de diversas maneras para atender los distintos usos sociales de las imágenes fotográficas consideradas documentales, sociales, científicas o artísticas. Si las vanguardias fotográficas de los años veinte tuvieron éxito en algo, fue en establecer, en sus relaciones con los mercados de arte y las políticas culturales, la artisticidad de la imagen fotográfica. Abrieron así un campo fértil para que la fotografía se considerara arte en nuestro país, aunque pocos exponentes fueron tomados en cuenta entonces como "artistas". Es a posteriori, en la escritura y revisión de la historia de la fotografía en México a partir de los ańos ochenta, cuando se han diversificado los campos de estudio para dar cuenta de las imágenes documentales (sobre todo del fotoperiodismo) y las artísticas, aunque en general se ha tratado la producción fotográfica privilegiando una perspectiva de "fotografía de autor". ${ }^{I}$ Las imá-

I. Véanse por ejemplo Rebeca Monroy, Historias para ver: Enrique Díaz, fotorreportero, México, Universidad Nacional Autónoma de México-Instituto de Investigaciones Estéticas/Instituto Nacional de Antropología e Historia, 2003, y John Mraz, Nacho López y el fotoperiodismo mexicano en los años cincuenta, México, Consejo Nacional para la Cultura y las Artes-Instituto Nacional de Antropología e Historia/Océano (Alquimia), I999, cuya versión en inglés incluye varias correcciones: Nacho López, Mexican Photographer, Minneápolis/Londres, University of Minnesota Press (Visible Evidence, I4), 2003. 
genes que consideraremos en este ensayo pueden inscribirse dentro de este esfuerzo por estudiar y comprender las diferentes maneras de ver, y fotografiar, de los fotorreporteros de los ańos treinta, que comparten el tratamiento del autor, pues se concentran en seguir el trabajo de Ismael Casasola.

Quiero mostrar aquí, a través de un estudio de caso y sin ser exhaustiva, la manera en que la fotografía y el texto se imbrican en el artículo “ ¡Vamos a ver al Pascola!", de Gregorio Ortega, con fotografías de Ismael Casasola, publicado por la revista $H_{o y}{ }^{2}$ Pueden analizarse desde la perspectiva de la cultura visual, como lo ha propuesto W.J. Thomas Mitchell sobre todo en su obra Picture Theory. ${ }^{3}$ Este artículo sobre la danza yaqui de la pascola, publicado en una de las revistas de amplia circulación de los años treinta, nos permite apreciar la forma en que texto e imágenes cooperan para construir un imaginario social indigenista que verán los habitantes capitalinos hacia mediados de 1939. Mi interés es el de articular, mediante este ejemplo, algunas diferencias entre los discursos que imágenes y textos promovieron sobre el danzante o pascola yaqui como depositario de las tradiciones milenarias de su grupo étnico, para así conformar uno de los fragmentos del entramado simbólico que entendemos como "imaginario social". " Debo aclarar que éste es un ejemplo entre otros de las décadas de los treinta y cuarenta en las revistas de amplia circulación. El contenido de estos artículos es de divulgación, a diferencia de los textos académicos que, desde la plataforma de las disciplinas sociales - la etnografía, la antropología y la sociología-, también promovieron ciertos modos de ver y conceptuar las culturas indígenas.

Desde el Renacimiento, la representación visual y textual de los grupos humanos no occidentales encontrados por los europeos durante la primera expansión colonial formó parte de la construcción de diferentes tejidos simbólicos sobre la diversidad y la otredad. En las pinturas de castas dieciochescas, por ejemplo, y sobre todo a partir del costumbrismo decimonónico en la gráfica y la pintura, se consolidó en nuestro país la empresa de representar visualmente la alteridad: los tipos populares, las clases sociales, los oficios, los grupos étnicos y las razas. Este tipo de representación respondió a un impulso

2. Gregorio Ortega, “¡Vamos a ver al Pascola!”, Hoy, vol. X, núm. I30, año 2, I9 de agosto de 1939 , s.p.

3. W.J. Thomas Mitchell, Picture Theory, Chicago/Londres, University of Chicago Press, I994.

4. Cfr. Bronislaw Baczko, Los imaginarios sociales. Memorias y esperanzas colectivas, Buenos Aires, Nueva Visión, I99I, pp. I I-53, y Benedict Anderson, Comunidades imaginadas. Reflexiones sobre el origen y la difusión del nacionalismo, México, Fondo de Cultura Económica, I993. Agradezco a Itzel Rodríguez Mortellaro que me recomendara y prestara estos libros. 
de clasificar a la sociedad en categorías cada vez más variadas, pero dependientes de un concepto de normalidad y moralidad al cual sólo la elite pertenecía. En el siglo XIX, las nacientes ciencias del hombre — antropología, etnografía y sociología-, ocupadas en constituir sus objetos de estudio y escrutinio desde el privilegiado lugar que su discurso científico les proporcionaba, contribuyeron de suyo a consolidar formas particulares de visualizar y conceptuar las culturas indias. Sin embargo, la literatura, la pintura, la gráfica y la escultura no se quedaron atrás y promovieron también ciertas imágenes de lo indio. ${ }^{5}$

Debe hacerse notar que desde las postrimerías del siglo xIx había precursoras mexicanas de revistas de gran formato como El Mundo Ilustrado, por ejemplo. Con el tránsito al siglo xx, en nuestro país se registró, al igual que en otras partes del mundo, un auge en la producción de revistas ilustradas encargadas, por medios multirreproductibles, de diseminar cada vez con mayor fluidez las imágenes de los diferentes ámbitos de la vida nacional. ${ }^{6}$ Muchos diarios y publicaciones periódicas sufrieron durante los años de la gesta revolucionaria la carencia del papel y la falta de recursos, sumando a sus limitaciones las que la prensa plana imponía en la reproducción de las fotografías. Con la llegada de la prensa rotativa, la inclusión de fotografías se hizo más factible y ya en la década de los años treinta irrumpió espectacularmente en los medios impre-

5. En la literatura de corte indigenista escrita en las décadas de los años treinta y cuarenta del siglo $\mathrm{xx}$, tenemos varios ejemplos; véase Sylvia Bigas Torres, La narrativa indigenista mexicana del siglo XX, Guadalajara/Puerto Rico, Universidad de Guadalajara/Universidad de Puerto Rico, I990. En cuanto a la pintura desde el XIX, véase Juana Gutiérrez Haces, "Etnografía y costumbrismo en las imágenes de los viajeros", en Elías Trabulse et al., Viajeros europeos del siglo XIX en México, México, Fomento Cultural Banamex, 1996, pp. I59-18I. Sobre ejemplos en la gráfica, véase Antonio Saborit, “Tipos y costumbres. Artes del callejero amor”, en Eloísa Uribe et al., Nación de imágenes. La litografía mexicana del siglo XIX, México, Instituto Nacional de Bellas Artes-Museo Nacional de Arte, 1994, pp. 56-69, y, sobre todo, María Esther Pérez Salas, Costumbrismo y litografía en México: un nuevo modo de ver, México, Universidad Nacional Autónoma de México-Instituto de Investigaciones Estéticas, 2005. Sobre la escultura puede consultarse Fausto Ramírez et al., Catálogo comentado del acervo del Museo Nacional de Arte. Escultura. Siglo XIX, México, Instituto Nacional de Bellas Artes-Museo Nacional de Arte/Universidad Nacional Autónoma de MéxicoInstituto de Investigaciones Estéticas, 2000, t. I, y 200I, t. II.

6. El Mundo Ilustrado, fundado en I894, fue precursor en el uso del "medio tono" para imprimir fotografías en sus páginas. Al importarse maquinaria europea para realizar rotograbados, las revistas y los libros ilustrados con fotografías se multiplicaron a partir de finales de los años veinte. Cfr. Rebeca Monroy, "Enrique Díaz y fotografías de actualidad (de la nota gráfica al fotoensayo)", Historia Mexicana, El Colegio de México, vol. XLVIII, núm. 2, octubre-diciembre de I998, pp. 379-380 y 385 . 
DOI: http://dx.doi.org/10.22201/iie.18703062e.2009.94.2286

96

DEBORAH DOROTINSKY ALPERSTEIN

sos. El lanzamiento de la revista Life en Estados Unidos (1936), en el formato que se conoce como tabloide $(27.94 \times 43.18 \mathrm{~cm})$, causó profundo efecto en los medios impresos del país y alentó el surgimiento de las revistas superilustradas con fotografías. ${ }^{7}$

En los años treinta y desde Europa, Walter Benjamin se preguntó acerca de los cambios que la fotografía, el cine y las bandas sonoras acarrearían a la estética tradicional. ${ }^{8}$ Según Benjamin, en las imágenes multirreproductibles, la eficacia expositiva de la imagen empezaba a eclipsar su valor cultural. Benjamin señaló, inadvertidamente, uno de los giros que más adelante darían los estudios en la historia del arte: de la creación de la obra como objeto contemplable a la recepción de ella.

\section{Cuadro-texto e historia}

El pensamiento sobre la interconexión entre el lenguaje escrito y la imagen en un cuadro es uno de los temas recurrentes en la historia del arte actual. ${ }^{9}$ Donald Preziosi, por ejemplo, se refiere a ella como el ejercicio de "hacer legible lo visible". ${ }^{\text {Io }}$ Una de las vertientes de desarrollo de esa relación se aprecia desde la Antigüedad en el género literario de la descripción conocido como ekphrasis. En su acepción actual, se entiende como la descripción tan vívida de

7. Entre las revistas ilustradas de las décadas de los ańos treinta y cuarenta, destacan la del tabasqueño Félix F. Palavicini, Todo (1933-1937); de sus paisanos los primos Regino Hernández Llergo y José Pagés Llergo, Hoy ("La revista supergráfica”, 1937), Rotofoto (1938), Mañana (1943) y Siempre! (1953). Cfr. Rebeca Monroy, "Del olor de la pólvora a la luz de los rascacielos: tres décadas de fotoperiodismo mexicano", en Esther Acevedo (coord.), Hacia otra historia del arte en México. La fabricación del arte nacional a debate (1920-1950), México, Consejo Nacional para la Cultura y las Artes, 2002, pp. I80-I8I.

8. Walter Benjamin, "La obra de arte en la época de su reproductibilidad técnica", en Discursos interrumpidos I, Madrid, Taurus (Serie Ensayistas, 9I), I973.

9. El término "imagen" es demasiado abstracto, ya que alude tanto a las figuras que formamos en nuestra mente como a las que vemos con nuestros ojos y a las construidas en un texto. En castellano podría emplearse el término "cuadro", que es el equivalente más cercano a lo que la palabra picture designa en inglés. Por desgracia, cuando usamos "cuadro", casi siempre nos viene a la mente una obra pictórica, lo cual limita la acepción general que picture tiene en inglés, que incluye de manera más generosa tanto a las pinturas como a las fotografías. Ésta no es una discusión ociosa para la cultura visual que trabaja con una amplia gama de objetos visuales; sin embargo, por ahora, a falta de un término más preciso, seguiré utilizando "imagen".

Io. Donald Preziosi (ed.), The Art of Art History, Oxford University Press, 1998. 
un episodio o un acontecimiento que éste parecería ocurrir realmente frente a nuestros ojos. ${ }^{\text {II }}$ Esto respondería, grosso modo, a una de las formas tradicionales de articular verbal y textualmente, sobre una obra pictórica, un contenido literario que en la actualidad es objeto de un proceso de revaloración (tal vez de franco rescate) en el pensamiento autocrítico del historiador de arte. Otra ruta relacionada con la primera se conoció desde el Renacimiento como la teoría de las artes hermanas y parece haberse originado con un malentendido del símil de Horacio ut pictura poesis (como la pintura, así la poesía). ${ }^{12}$ Lo que quiero destacar es que, desde la tradición de la Historia del Arte, ha quedado claro que palabras y cuadros sostienen fuertes lazos entre sí.

El poeta y crítico de arte Octavio Paz relata que a la fotografía le debía una de sus primeras experiencias artísticas: cuando era un joven de apenas i6 años, tenía en la revista Contemporáneos una de sus lecturas favoritas, pues a él y sus compañeros los llenaba a la vez de estupor y curiosidad mediante los textos, no siempre comprendidos, de Valéry, Perse, Borges, Neruda o Villaurrutia. Relata Paz que un día, al hojear el número 33 (febrero de 193I), se topó con tres fotografías de Manuel Álvarez Bravo que le provocaron una turbación extraña:

aquellas fotos eran enigmas en blanco y negro, callados pero elocuentes: sin decirlo, aludían a otras realidades y, sin mostrarlas, evocaban a otras imágenes. Cada imagen convocaba, e incluso producía, otra imagen. Así, las fotos de Álvarez Bravo fueron una suerte de ilustración o confirmación visual de la experiencia verbal a la que me enfrentaba diariamente en mis lecturas de los poetas modernos: la imagen poética es siempre doble o triple. Cada frase, al decir lo que dice, dice otra cosa. La fotografía es un arte poético porque, al mostrarnos esto, alude o presenta aquello. Comunicación continua entre lo explícito y lo implícito, lo ya visto y lo no visto. El dominio propio de la fotografía, como arte, no es distinto al de la poesía: lo impalpable y lo imaginario. ${ }^{13}$

I. Michael Baxandall, Modelos de intención. Sobre la explicación histórica de los cuadros, Madrid, Hermann Blume, I989; Svetlana Alpers, "Ekphrasis and Aesthetic attitude in Vasari's Lives", Journal of the Warburg and Courtland Institutes, núm. 23, 1960, pp. 190-215.

I2. Rensselaer W. Lee, Ut pictura poesis. La teoría humanistica de la pintura, Madrid, Cátedra, I982, pp. I3-I7.

13. Octavio Paz, "Instante y revelación: Manuel Álvarez Bravo", en Paz, Obras completas, Los privilegios de la vista II: Arte de México, México, Fondo de Cultura Económica (Círculo de Lectores), 2003 , p. 315. Este texto apareció originalmente como prólogo del libro Instante y revelación 
Paz propone así una versión de la tradición del ut pictura poesis, extendida a la fotografía artística. El lazo aquí entre la poesía y la fotografía es curioso: las fotografías de Álvarez Bravo se le presentaron a Paz como "una suerte de ilustración o confirmación visual de la experiencia verbal". Ilustración o confirmación el puente que tiende Paz entre la imagen y la letra es uno de esos puentes flexibles, de cuerdas y maderas que se mecen con el viento y provocan vértigo al que los cruza, y no la estructura sólida y firme de alguna de esas impresionantes obras de ingeniería que atravesamos en la Carretera del Sol. Idílica y hermosa relación la que nos plantea el poeta, aunque no siempre firme, si pensamos en la rivalidad que nació, desde el Renacimiento, entre la poesía y la pintura por el monopolio en la representación del mundo. El "Parangón" en el Tratado de la pintura de Leonardo da Vinci es un excelente ejemplo de esta contienda llevada al extremo para lograr que se reconociera a la pintura como arte liberal, como la música o la poesía. ${ }^{14}$

En términos generales, al historiar el problema de la relación cuadro-texto nos percatamos de que uno de sus puntos nodales lo constituye la lucha por monopolizar el derecho incuestionable a representar el mundo. Desde la perspectiva lingüística, la obra de arte se ha definido como una representación semiótica, es decir, un sistema de signos que rompe con la concepción tradicional del arte en términos de mímesis. Sin embargo, algunos autores, como Gombrich, por ejemplo, distinguieron entre signos naturales y signos convencionales para argumentar que el signo visual, siendo natural, hacía a las imágenes superiores a los signos lingüísticos. ${ }^{\text {I5 }}$

La cultura visual ofrece una puerta de salida de este estrecho laberinto - habrá que cuidarse de que no se trate de una puerta falsa-, al plantear que hay textos pictóricos y cuadros textuales. Es decir, hay una relación entre las palabras y los cuadros y, aunque muchas veces parecen estar en los polos opuestos de un espectro de sentido, a menudo coexisten y colaboran en un campo donde generan tensiones que influyen en la tarea de construir un dis-

(treinta poemas de Octavio Paz y sesenta fotografías de Manuel Álvarez Bravo), México, I982, y luego con el mismo título en Sombras de obras, Barcelona, Seix Barral, I983.

I4. Leonardo da Vinci, "Parangón", en Tratado de la pintura, México, Ramón Llaca, I996, pp. 25-86 [primera ed. I65I].

15. Cfr. las ideas de Mitchell sobre la oposición naturaleza-convención en el trabajo de Gombrich, en W.J. Thomas Mitchell, Iconology: Image, Text, Ideology, Chicago/Londres, University of Chicago Press, 1986, pp. 76-94. 
curso. ${ }^{16}$ Es tal asunto de colaboración el que va a interesarnos más en nuestro análisis del fotoperiodismo.

Para teóricos estadounidenses como Mitchell, que promueven la perspectiva de la cultura visual, la imagen es un término, pero también un dispositivo que nos sirve para pensar el mundo: el de las representaciones en particular. ${ }^{17}$ En Iconology: Image, Text, Ideology, Mitchell realiza un acercamiento al tema de la tensa relación entre las imágenes, los textos y la ideología, y propone una tipología de las primeras y de las disciplinas con que se relacionan. En la práctica, es decir, en la manera en que se utilizan, las imágenes pueden acomodarse en una relación que va de lo visual hasta lo verbal. El esquema que plantea Mitchell sirve básicamente para introducir la idea de que son dos los tipos de imágenes que se encuentran en polos opuestos: las gráficas (objetos materiales como cuadros, estatuas, diseño gráfico e industrial, caricaturas, fotografías, entre otros) y las verbales y escritas. Este investigador cuestiona la concepción aristotélica según la cual los seres humanos pensamos en imágenes, ${ }^{18} \mathrm{y}$ concluye que ella no puede ser cierta, ya que de hecho lo hacemos de modo multisensorial, mezclando el tacto, el olfato, el oído, el gusto y la vista. De este modo, Mitchell sustituye el argumento aristotélico que opone lo sensible a lo inteligible (fenómenos de la sensación o aisthesis versus fenómenos del intelecto o noesis), por una contraposición entre las formas visuales y los conceptos lingüísticos. ${ }^{19}$ La postura adoptada por este profesor de la Universidad de

16. Mitchell, Picture Theory, op. cit.

17. Mitchell, Iconology ..., op. cit., p. I I.

I8. En el Tratado de la memoria y la reminiscencia, Aristóteles aclara que la memoria no se confunde ni con la sensación ni con la concepción intelectual, y que sólo los animales que poseen percepción del tiempo tienen memoria. A esto agrega: "Ya hemos hablado anteriormente de la imaginación en el Tratado del alma, donde hemos dicho que no se puede pensar sin imágenes [...] Evidentemente debe creerse que la impresión que se produce en el alma como resultado de la sensación y en esta parte del cuerpo que percibe la sensación, es análoga a una especie de pintu$r a$, y que la percepción de esta impresión constituye precisamente lo que se llama memoria" (las cursivas son mías). Aristóteles, "Tratado de la memoria y la reminiscencia”, en Obras completas, Buenos Aires, Bibliográfica Omega, 1967, t. III, cap. I, pp. 93-95.

19. Aristóteles no niega la posibilidad de que la percepción sensorial sea simultánea, es decir, que se produzca merced a más de uno de los sentidos. Cfr. Aristóteles, "Conclusión de la teoría de la sensibilidad", en "Plan general del tratado del alma", en Tratado del alma, ibidem, t. II, lib. III, p. 424. Lo que sí aclara más adelante es que "Es preciso distinguir con cuidado la imaginación de la sensación y del pensamiento intelectual. Es cierto que la imaginación no se produce sin la sensación, y que sin ella tampoco es posible la concepción a la inteligencia; pero la concepción y el pensamiento no se confunden", p. 427. 
Chicago bien puede considerarse vinculada con el giro lingüístico impulsado por varias disciplinas humanísticas y sociales en Estados Unidos hacia 1980. ${ }^{20}$

En un libro posterior, Picture Theory, Mitchell vuelve a formular muchas de las preguntas que se hizo en Iconology..., pero ahora de una manera más pragmática, llena de ejemplos y escrita de forma didáctica. El autor se interroga: ¿qué es un cuadro?, y descubre, al intentar responder, que no puede hacerlo sin extenderse a los textos, en particular a las diversas maneras en que los textos actúan como cuadros o "incorporan” prácticas pictóricas (y cómo los cuadros incorporan prácticas textuales). Por ello, desiste de su empeño de oponer lo visual y lo lingüístico para considerar la interacción entre imágenes visuales y textuales. En el centro de la diferencia entre el texto y el cuadro se encuentra una "heterología" de la representación, pero no una dicotomía polarizada entre uno y otro modos de representar. Ambos medios de construcción-representación, explica el autor, compiten por mantener cierto grado de poder o predominio en los sistemas de representación del mundo. ${ }^{21}$

En el capítulo cuarto de ese libro, dedicado al fotoensayo, Mitchell logra mostrar de manera clara, y muy concreta, cómo el texto y la imagen fotográfica se imbrican en la representación del mundo. Estas dos partes que conforman el fotoensayo a veces cooperan, a veces se resisten una a la otra, a veces son independientes y evocan en el receptor emociones encontradas y antagónicas, pero, cuando actúan en conjunto, una fotografía y un texto - como en los ejemplos que evoca: las fotografías del libro La cámara lúcida, de Roland Barthes, con que se crea la impresión de un laberinto, o las de Jean Mohr y los textos de Edward Said sobre líderes palestinos en el exilio- muestran en su colaboración la lucha que uno y otro medio libran por el poder en cuanto a la representación contemporánea de la realidad. El fotoensayo es para Mitchell el espacio privilegiado donde podemos apreciar que "la relación de la fotografía y el lenguaje es un sitio capital de lucha por el poder y la valoración en las representaciones contemporáneas de la realidad; es el lugar en el que imágenes y palabras encuentran y pierden su conciencia, su estética, su identidad

20. Éste puede considerarse un segundo giro lingüístico, posterior al que siguió a los trabajos de Saussure en la primera mitad del siglo xx. Algunos autores lo identifican como un fuerte coqueteo de los intelectuales estadounidenses con el estructuralismo francés y luego con el posestructuralismo y la deconstrucción derrideana.

2I. Esta lucha de poder puede resumirse en las posturas contemporáneas de iconofílicos contra iconofóbicos. 
ética". ${ }^{22}$ En estos encuentros necesarios entre fotografía y palabras dentro del fotoensayo y el fotorreportaje, encontramos el espacio de la dramatización de las preguntas sobre la identidad, la ética y la estética. Quizá las palabras de Mitchell no tendrían tanta relevancia si no fuera porque de hecho una de las rutas más transitadas de la historia de la fotografía en nuestro país es justamente la del análisis de la fotografía de prensa y la de la utilidad de relacionar textos y fotografías $-o$ textos y grabados en siglos anteriores al advenimiento de la fotografía - para constituir, reportar, construir y controlar la identidad de clase, de género o la política. El ensayo fotográfico es para este autor una dramatización de tales tensiones y el tropos desde el cual surge una forma mixta, un arte compuesto (composite art). La fragmentación, los pedazos de los que se componen fotorreportaje y fotoensayo remiten además a la importancia que la serie fotográfica tiene en la articulación de una estructura narrativa. ${ }^{23}$

La fotografía ocupa un lugar singular en las discusiones sobre esta relación cuadro-texto o imagen-texto, en virtud de su supuesta característica mimética y el alto valor documental que de ella se deriva. Hoy día se considera la fotografía más bien como una construcción donde los encuadres, la toma desde un punto de vista, los ángulos y los cortes temporales (eso que Henri CartierBresson llamó "el instante decisivo") se entienden como parte de una sintaxis: sistemas organizados de signos que forman parte de diferentes estrategias de

22. Mitchell, "The Photographic Essay: Four Case Studies", en Picture Theory, op. cit., p. 28 I ("The relation of photography and language is a principal site of struggle for value and power in contemporary representations of reality; it is the place where images and words find and lose their conscience, their aesthetic and ethical identity").

23. Tanto John Mraz como Rebeca Monroy dedican espacio en sus trabajos a la clasificación de las notas que aparecieron en las revistas ilustradas, sobre todo con el fin de señalar las diferencias y establecer ciertas tipologías. Monroy diferencia la nota gráfica (con una sola imagen) del fotoensayo y el fotorreportaje; Mraz a estos dos últimos. La clasificación no es del todo ociosa. El fotorreportaje se caracteriza por ofrecer datos de carácter informativo, como los relativos a un acontecimiento o noticia de ocasión; quien lo escribe y el fotógrafo que aporta las imágenes son en general dos personas diferentes. El fotoensayo, salvo algunas excepciones, brinda una perspectiva más bien "autoral", pues la redacción del texto y la selección de la secuencia fotográfica son obra del fotógrafo mismo, como es el caso de Nacho López, uno de los más destacados fotoensayistas de México. Lo anterior pone de relieve que el fotoensayo trata un hecho cotidiano, que narra y construye mediante textos y fotografías. Esto lleva a pensar que una de las maneras en que se pudo conocer el mundo de los ańos treinta y cuarenta del siglo xx, y en que aún se conoce ahora, la constituyen esos fotoensayos y fotorreportajes que no sólo construyen imaginarios, sino que desde el siglo xx son modos de ver en sí. 
significación, una sintaxis que se ve cruzada por el bagaje cultural de quien opera la cámara, comisiona las imágenes, etcétera.

Estos signos fotográficos, que en sí contienen información de corte histórico - quién estaba con quién en un lugar determinado, cómo se vestía la gente de las diferentes clases sociales, cómo se veían los gobernantes-, además han sido abordados e interpretados para construir discursos históricos, por lo que son susceptibles de un análisis historiográfico. ${ }^{24}$ Las fotografías aisladas pueden o no impulsar un discurso histórico, según nuestra interpretación de los signos como contenedores o no de cierta narrativa. Lo que es cierto, como afirma John Berger, es que la imagen fotográfica plantea "otra manera de contar", distinta a la de un texto escrito. ${ }^{25}$ Puede considerarse que cuando aparece acompañada de un texto y, más aún, cuando se la encuentra impresa en una revista dentro de una serie o secuencia, entonces el conjunto fotografía-texto propone un muy peculiar discurso histórico: la secuencia fotográfica adquiere una duración en el tiempo análoga al decurso narrativo del texto escrito. Estas secuencias o series pueden aparecer también dentro de álbumes fotográficos donde en ocasiones se crean sistemas de equivalencias, de atracción o de repulsión entre las imágenes. ${ }^{26}$ Incluso los investigadores pueden armar las secuencias y las series con que se puede proponer un determinado discurso llamado histórico. Los discursos fotográficos de las revistas también adoptan las estrategias dramáticas cinematográficas, convirtiendo así al fotorreportaje y al fotoensayo en una suerte de películas congeladas.

Si la fotografía aislada contiene un discurso histórico, lo propone, lo construye, el problema radica en encontrar la manera de "hacer hablar a la imagen", lo que posiblemente se ha logrado mediante pies de foto, expedientes, cartas,

24. De acuerdo con Charles Sanders Peirce, el signo fotográfico puede considerarse indicial, icónico o simbólico. Cfr. Phillipe Dubois, El acto fotográfico. De la representación a la recepción, Barcelona/Buenos Aires/México, Paidós (Comunicación, 20), 1986.

25. John Berger y Jean Mohr, Otra manera de contar, Murcia, Mestizo (Palabras de Arte, 3), I997 (ed. original en inglés, 1982). Berger insiste en que las fotografías en secuencia no generan una narrativa estricta, sino más bien un "montaje de atracciones", donde las imágenes se conectan en doble sentido (hacia la que antecede y también a la que le sigue), y por ello no operan de igual modo que la narración escrita, cuya progresión va "hacia delante" (pp. 288-289). Consideradas en una interrelación "multidireccional", las fotografías remiten no al contexto "temporal" original en que se tomaron —eso sería imposible—, sino a un contexto de experiencia. Habría que ponderar con mayor detenimiento si en la fotodocumentación hay o no una suerte de diégesis cinematográfica.

26. Deborah Poole, Vision, Race and Modernity; A Visual Economy of the Andean Image World, Princeton University Press, I997, pp. I07-I4I. 
interpretaciones escritas y exposiciones museísticas, por lo que podemos plantear la posibilidad de que sea susceptible de un análisis historiográfico. Sin embargo, los mismos modos fotográficos de ver — ciertas preferencias puramente fotográficas, como los encuadres, los géneros (paisaje, retrato, entre otros), los tipos de lentes, focos, soportes y técnicas de impresión-, por ser elecciones que significan, resultan en sí susceptibles de un acercamiento historiográfico.

El historiador del arte sabe, está consciente de que su interpretación de la imagen se ancla no sólo en su conocimiento de las fuentes iconográficas, sino en la existencia de documentación escrita relativa al periodo en que se produce la obra. ${ }^{27}$ Estas fuentes se complementan para reconstruir la manera específica de ver el mundo de una sociedad o cultura, los "modos de ver" en un momento histórico concreto. ${ }^{28}$

\section{“¡Vamos a ver al Pascola!”}

El artículo que nos ocupa apareció publicado en la revista Hoy en agosto de 1939, ${ }^{29}$ con texto de Gregorio Ortega y fotografías de Ismael Casasola. ${ }^{30} \mathrm{~A}$ través de los artículos de temática indigenista que aparecieron en esta revista, más que con los de corte científico publicados en los Anales del Museo Nacional o la Revista Mexicana de Sociología, podemos comprender una "mirada divulgadora" de la diversidad étnica del país. Fueron las revistas ilustradas las encargadas de conformar y difundir ciertos imaginarios sociales que tuvieron mayor recepción entre la gente y, por tanto, suponemos que contribuyeron en mayor grado a consolidar estereotipos y actitudes frente a la población india en la década de los cuarenta. ${ }^{31}$ La relevancia histórica e historiográfica de este tipo

27. Erwin Panofsky, Estudios sobre iconología, Madrid, Alianza, I972.

28. Cfr. Peter Burke, "El testimonio de las imágenes", en Visto y no visto. El uso de la imagen como documento histórico, Barcelona, Crítica, 200I, pp. I I-24.

29. Ortega, op. cit.

30. Formado en las filas de Hoy, el periodista Gregorio Ortega se convirtió en director de la revista América. Cfr. Monroy, "Del olor de la pólvora...", op. cit., p. I8o. Según el periodista Edmundo Valadés, jefe de redacción de la revista Hoy, entrevistado por Monroy, el grupo de "Fotografías de actualidad" de Díaz, Zendejas y Delgado, así como Ismael Casasola, constituía la planta de fotógrafos de Hoy. Cfr. Monroy, "Enrique Díaz y...", op. cit., p. 4 or.

3I. Con un costo de 60 centavos, Hoy tenía como director general a Regino Hernández Llergo, como administrador a Jacobo Martínez Llergo, como jefe de redacción a Edmundo Valadés, como secretario de redacción a René Tirado Fuentes y como jefe de publicidad al que fue "as de los anuncios" en El Nacional, Edmundo Arrache. Se decía que en la casa donde se encontraba la 
de reflexiones sobre la consolidación de entramados simbólicos radica no solamente en la comprensión de estos fragmentos del pasado, sino en que la historicidad de los discursos nos lleva a reflexionar de igual modo sobre el lugar de las imágenes de ayer en los imaginarios indigenistas de nuestros días.

Los yaquis, al igual que los mayos, seris y otros grupos indios del norte del país, particularmente los nómadas o seminómadas, fueron parte de la familia de grupos indios "bravos", es decir, los que se defendían y resistían los esfuerzos civilizadores: atacaban a los pueblos, robaban mujeres y ganado, eran cazadores feroces y muy dignos. Este estereotipo cristalizado en el siglo XIX, y sobre todo durante la guerra yaqui del Porfiriato, no dejó de promoverse en el siglo $\mathrm{xx} .{ }^{32}$ Otras fuentes consultadas para terminar de figurar tal imaginario social sobre el danzante yaqui, lo más contemporáneas posibles a la nota ilustrada, muestran que el estereotipo pervive. Lo encontramos en la narrativa de la época, como por ejemplo en el cuento corto "La triste historia del 'pascola' Cenobio", de Francisco Rojas González. Ahí, el escritor pinta al lector un personaje similar al que construye el periodista en el artículo que trataremos. En ese relato, Rojas González narra en un tono casi tragicómico el destino del joven danzante Cenobio Tanori, quien, al no poder mantenerse con las flacas recompensas obtenidas por su arte, se alquila como guía de un gambusino blanco, transgrediendo así las normas tácitas de la comunidad en lo tocante a la relación con los fuereños. Trabajar para el yori resulta un grave atentado contra la dignidad de la tribu y Cenobio provoca el rechazo de los viejos. Mirando a través del prisma que su entrenamiento como sociólogo le proporciona, el escritor jalisciense logra plasmar el proceso de ensanchamiento de la brecha generacional dentro de la comunidad. Los que muestran su desprecio son los ancianos, condensados en el personaje colectivo de Miguel Tojíncola. Éste, borracho, confronta a Cenobio, lo insulta y le escupe en la cara, motivo por el cual Cenobio lo apuñala y mata, acto que simbólicamente puede significar un atentado en contra de la tradición y los viejos valores, o incluso un aniquilamiento de ellos. El destino del joven pascola queda en ma-

redacción "había fantasmas", en particular el del general Sóstenes Rocha. Así lo describe Ortega en el número del segundo aniversario de Hoy, del 4 de marzo de 1939.

32. Cfr. Héctor Cuauhtémoc Hernández Silva, Insurgencia y autonomía de los pueblos yaquis: I82I-1910, México, Centro de Investigaciones y Estudios Superiores en Antropología Social/ Instituto Nacional Indigenista, 1996, y Cécile Gouy-Gilbert, Una resistencia india. Los yaquis, México, Instituto Nacional Indigenista/Centre d'Études Mexicaines et Centraméricaines (Serie de Antropología Social, 7I), I985. 
nos de las autoridades tradicionales y la multitud enardecida que clama por su muerte. Sin embargo, el derecho consuetudinario actúa en favor de la anciana viuda de Tojíncola y sus nueve hijos, y el consejo dicta que el pascola deberá casarse con ella y cuidar de su prole. La tradición y la costumbre plasmadas en las líneas de Rojas González actúan para proteger a los desvalidos, y a la vez desencadenan toda la fuerza trágica del relato. Así termina el hermoso pascola "de torso hercúleo", por el que suspiraban las jovencitas de la tribu: ha perdido sus bríos estereotípicos y camina "con la cabeza gacha, arrastrando sus pies, ridículo como un títere".

En la etnografía, contamos con varios ejemplos que tratan las características culturales del grupo yaqui. En 1936 apareció Studies of the Yaqui Indians of Sonora, Mexico, editado por William Curry Holden, en el cual se nos ofrece un apartado especial dedicado a las fiestas fúnebres y las danzas. ${ }^{34}$ En 1940, Alfonso Fabila publicó Las tribus yaquis de Sonora..., editado por el Departamento de Asuntos Indígenas con motivo del Primer Congreso Indigenista Interamericano. ${ }^{35}$ Edward H. Spicer, quien se convertiría con los años en el etnólogo especialista de la mencionada etnia, publicó ese mismo año "The Yaqui Indians of Arizona". ${ }^{6}$ Desde las filas del Instituto de Investigaciones Sociales de la Universidad Nacional Autónoma de México, Luis Arturo González Bonilla escribió el artículo "Los yaquis", que apareció en la Revista Mexicana de Sociología ilustrado con fotografías del archivo "México Indígena” de dicho

33. Francisco Rojas González, "La triste historia del 'pascola' Cenobio", en Cuentos completos, México, Fondo de Cultura Económica, 1996, p. 368. Este relato forma parte de la colección póstuma El diosero, publicada en 1952, aunque seguramente escrita durante los años cuarenta.

34. Mismo que también apareció publicado como artículo en William Curry Holden et al., "Studies of the Yaqui Indians of Sonora, Mexico", Texas Technological College Bulletin, vol. XII, núm. I, enero de 1936. Esta expedición partió en 1934. Los doctores C.J. Warner (jefe de personal del West Texas Hospital) y Richard Arthur Studhalter (profesor de biología del Texas Technological College) tomaron cerca de 600 fotografías y filmaron i 200 pies de película.

35. Alfonso Fabila, Las tribus yaquis de Sonora. Su cultura y anhelada autodeterminación, México, Departamento de Asuntos Indígenas, 1940. Fabila fue enviado por la Secretaría de Educación Pública (SEP) a realizar un estudio sobre el sistema escolar de las tribus yaquis de Sonora, pero como el material recolectado excedió las necesidades del informe, Fabila lo reunió en el libro, además de presentar el informe escolar. Esta obra también se ilustra con fotografías que pueden consultarse en el fondo que lleva el nombre de Fabila en el Archivo Etnográfico y Audiovisual del antiguo Instituto Nacional Indigenista, hoy Fototeca Nacho López de la Comisión Nacional para el Desarrollo de los Pueblos Indígenas.

36. Edward H. Spicer, "The Yaqui Indians of Arizona", Kiva, vol. 5, I940, pp. 2 I-24. 
instituto. ${ }^{37}$ Este último texto se divide en apartados, por ejemplo historia, clasificación lingüística, localización geográfica, matrimonio, ceremonias, danzas y patología, e incluye un curioso apartado sobre relaciones sexuales. ${ }^{38}$ El ensayo de González Bonilla empieza reforzando el estereotipo nómada y guerrero del yaqui: "La región habitada por los viejos yaquis es difícil de precisar, en razón de que esta tribu vivía dispersa en una amplia zona montañosa, inaccesible, dada la conocida agresividad y fiereza de estos indios". ${ }^{39}$ Las fotografías que lo ilustran muestran primero el "tipo" físico de hombres, mujeres y niños, con tomas de frente y de perfil, fondos neutros y un primer plano americano muy cerrado, y en ocasiones de cuerpo entero. Hay también una fotografía de una pareja de músicos (violinista y arpista) y una casa-habitación que incluye dos planos: una elevación de la vivienda y una planta de ella. Por su parte, Carlos Basauri, en La población indígena de México, también incluye una síntesis monográfica de este grupo y dedica un apartado especial a las danzas..$^{40}$ Basauri no se refiere en particular al danzante ni caracteriza de modo preciso a los hombres yaquis. Las fotografías que acompañan a los textos etnográficos en los años cuarenta son retratos de frente y de perfil, donde se intenta resaltar las características fisonómicas y no dar cuenta, visualmente, de una práctica cultural.

\section{"Un hombre alto y fuerte..."}

El propósito del reportaje de la revista Hoy es el de relatar la asistencia, casi fortuita, del periodista y el fotógrafo a una velación en el valle del Mayo donde presenciaron una danza "pascola". El texto es ambiguo y muy confuso respecto al grupo étnico en medio del cual se encuentran los dos enviados de la revista; a veces afirman estar entre los indios yaquis, y otras entre los mayos. ${ }^{4 \mathrm{I}}$ Carlos

37. Luis Arturo González Bonilla, "Los yaquis", Revista Mexicana de Sociología, vol. 2, núm. I, enero-marzo de 1940, pp. 57-88.

38. Según González Bonilla, el cuadro de danzas de los yaquis recibe el nombre de pascola y se acostumbra en las fiestas religiosas y en ocasión de la muerte de algún miembro de la tribu. Las danzas más conocidas son la pascola, el venado y el coyote. González Bonilla, op. cit., pp. 69-70.

39. Ibidem, p. 57.

40. Carlos Basauri, "Los yaquis", en La población indígena de México, 2a ed., México, Instituto Nacional Indigenista/Consejo Nacional para la Cultura y las Artes, I990, t. I [primera ed. 1940]. 4I. Los ocho pueblos yaquis eran Belem, Huíviris, Rahum, Pótam, Vícam, Tórim, Bácum y Cócorit. 
Basauri aclaraba en 1940, al referirse a los mayos en La población indigena de México, que

las tribus yaqui y mayo están íntimamente ligadas por sus rasgos raciales, parentesco de lengua, semejante cultura e historia, al grado de confundirse una con otra, y como los investigadores las consideran un solo grupo, se tratarán en forma muy breve los datos que se tienen, en especial de la tribu mayo. ${ }^{42}$

En particular me interesa esta renuncia a diferenciar. Mayos y yaquis habían realizado alianzas muy distintas con el gobierno desde la Revolución y habían sostenido políticas de defensa y resistencia étnica casi opuestas. ¿A qué responde esta tendenciosa vaguedad que los confunde? Podría obedecer, por un lado, a una ignorancia generalizada sobre las características culturales concretas de cada grupo étnico, ya que, como indicó antes, las publicaciones especializadas y más sistemáticas se inician formalmente a partir de la década de los cuarenta y, en ese sentido, nuestro estudio de caso es representativo del imaginario social indiferenciado de esas dos etnias que la prensa y otras fuentes de divulgación alentaban.

El relato comienza así: "Epifanio Durán, que pasa de los cuarenta, que es hombre musculoso, prieto, derrochador y socarrón, es una de las prendas de Navojoa". A un costado de estas líneas preliminares, que permiten empezar a imaginar al personaje del que trata el reportaje, aparece la fotografía de una figura masculina recortada, donde el contexto original se ha eliminado debido a que en la revista la imagen se encuentra recontextualizada a un costado de la narración escrita (fig. I). Solo y aislado, el hombre está retratado de perfil, en un muy marcado ángulo contrapicado. Un sombrero cubre su cabeza y sombrea las facciones superiores de su rostro. Viste una camisa de algodón, una pañoleta enlazada al centro sobre el pecho, pantalón de mezclilla y un grueso cinturón de piel. La figura hierática de este hombre, que toca un tamborcillo con dos bastones de madera, ocupa casi la página completa.

La importancia metodológica de la realización de este apunte formal radica en que, a través de ella, como ejercicio reflexivo, es posible detectar alguna información que de otra manera podría pasar inadvertida. Por ejemplo, el hombre no está vestido como los danzantes que vemos en la página siguiente; su atuendo es en realidad similar al que usaban normalmente los campesinos mestizos y

42. Basauri, "Tribu: mayos", en op. cit., p. 244. 


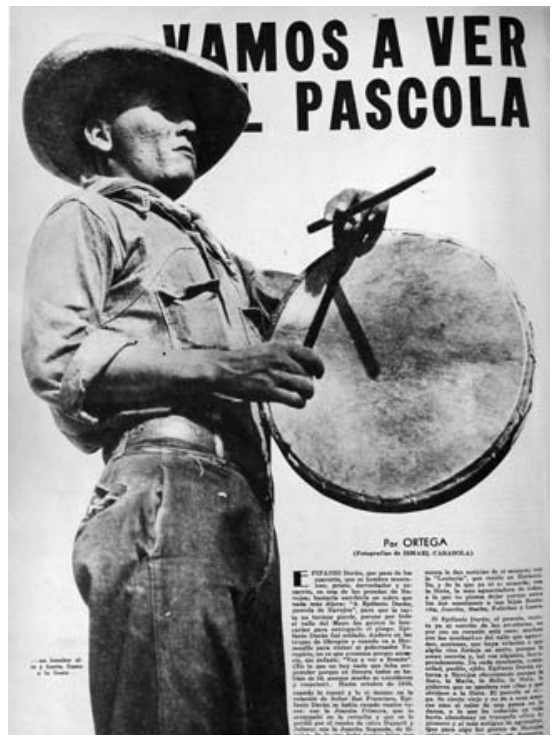

I. Gregorio Ortega, “¡Vamos a ver al Pascola!”, Hoy, vol. X, año 2, núm. I 30, I9 de agosto de I939, s.p. Foto: Ismael Casasola. Hemeroteca Nacional, unAm.

blancos de la región, salvo la distintiva pañoleta que tanto yaquis como mayos solían usar. ${ }^{43}$ A partir de esta primera descripción formal, es posible pasar a un análisis de los elementos visibles en la imagen para tratar de interpretarlos con la connotación histórica del documento, asunto que trataré de ilustrar enseguida.

Lo primero que destaca es la manera en que se ha revalorado a la imagen, si se la compara con las que aparecen en pequeños recuadros de la página opuesta (fig. 2). Los ángulos contrapicados fueron un recurso técnico-expresivo muy común en la época de los años treinta y cuarenta, tanto en México como en Estados Unidos y Europa. El origen estilístico de este tipo de tomas

43. Carlos Basauri sí aclara que la indumentaria de los yaquis "es casi igual a la que usa la gente del campo en Sonora y superior a la de muchas tribus de la República, y aun supera a la de la clase campesina del centro". Basauri, "Yaquis", op. cit., p. 224. Lo mismo menciona Fabila, op. cit., p. I32. En cambio, Ortega no reflexiona sobre este asunto y describe la vestimenta del danzante sin aclarar que ese atuendo es circunstancial y no de uso cotidiano. Por su lado, Spicer señala que la manera de vestir de los pascolas en Pótam era similar en esas fiestas a la de los yaquis que habían emigrado a Arizona. Cfr. Edward H. Spicer, Potam. A Yaqui Village in Sonora, American Anthropologist (Memoir, 77), vol. 56, núm. 4, parte 2, agosto de 1954, pp. 75-76. Además de bailar, aclara Spicer, el pascola era conocido y reconocido por su capacidad de contar historias, entonar cantos y proporcionar un entretenimiento muy apreciado por los yaquis, lo cual, en mi opinión, Rojas González ya refleja en su cuento. 
2. Gregorio Ortega, “ $¡$ Vamos a ver al Pascola!”, Hoy, vol. X, año 2, núm. I zo, I9 de agosto de I939, s.p. Foto: Ismael Casasola. Hemeroteca Nacional, UnAM.

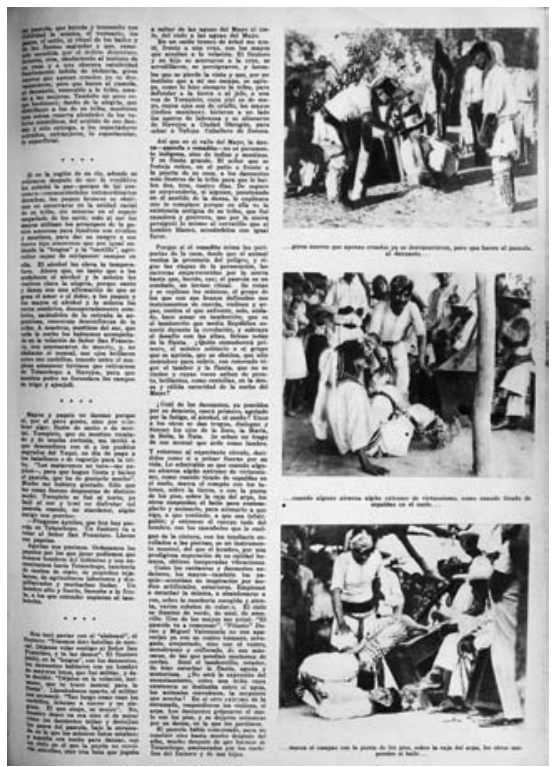

que agrandan la figura humana llega a la fotografía constructivista soviética, que hereda a la fotografía de documentación social de los años treinta y cuarenta la consigna de elevar ideológicamente a los personajes retratados haciéndolos parecer visualmente monumentales. ${ }^{44}$ En Estados Unidos, fotorreporteros de la Farm Security Administration como Dorothea Lang y Walker Evans practicaron este tipo de tomas al retratar a los granjeros desplazados durante la gran depresión de los años treinta. Este recurso expresivo cumplió la función ideológica de dignificar a ciertos segmentos de la sociedad — los trabajadores - para afirmar su valía dentro del imaginario social de la época. ${ }^{45}$

A la izquierda de la fotografía del hombre con el tambor, en letra pequeńa, se lee el pie de la foto: "un hombre alto y fuerte, llama a la fiesta". Juntos, este pie de foto y la imagen funcionan como preludio; inauguran literal y figurativamente el artículo del mismo modo que el tamborilero inaugura la pascola al

44. Cfr. Margarita Tupitsyn, The Soviet Photograph, 1924-1937, New Haven, Yale University Press, $c a$. 1996.

45. Naomi Rosenblum, $A$ World History of Photography, Nueva York/Londres/París, Abbeville Press Publishers, I997, pp. 366-377. 
convocar con el sonido de su tambor a los danzantes y espectadores. A pesar de que el texto versará sobre la danza y el bailarín principal, el editor ha dado el mismo orden al artículo que el que posee la práctica cultural descrita: el inicio es el llamado del tambor. De este modo, se empatan el orden visual y textual de la narración y el del hecho social. Sin embargo, la fotografía inicial no refuerza el relato escrito sobre el danzante. La figura de éste no aparece resaltada hasta una página después, en una fotografía de mayor formato donde lo vemos acompañado por uno de los músicos y el público que lo observa. Ésta es sin duda la mejor toma de Ismael Casasola para esta nota (fig. 3). La calidad de esa imagen se debe a la composición equilibrada y la limitada profundidad de campo que deja a las figuras del fondo, los niños, fuera de foco para resaltar así a los dos actores principales: el tamborilero-flautista y el danzante. ${ }^{46}$ Así, se aprecian con claridad tanto la expresión del músico como el atuendo y esfuerzo físico del bailarín. Además, el formato apaisado permite a Casasola ofrecer una vista más panorámica de la escena. La imprecisión del fondo, particularmente en el costado derecho, fuerza nuestra mirada a concentrarse en la figura del bailarín, que extiende la mano para recibir la percusión de la sonaja y eleva del suelo el talón de un pie, con lo cual provoca una impresión de movimiento congelado. Al mismo tiempo, la luz que penetra por el costado izquierdo, en la parte abierta de la enramada, ilumina y define la figura del músico.

Considero que la construcción de género, tanto del tamborilero como del danzante, es una de las cuestiones de mayor peso en el reportaje. Si bien la fotografía que inaugura el texto no es la de Epifanio Durán, que no es músico sino danzante, la intención, en primera instancia, consiste en crear en la mente del lector la figura de un personaje varonil y viril. En segundo lugar, se empezará a dar forma a los personajes que participan de la pascola —el tamborilero, el danzante, los músicos y los espectadores- y así se irá construyendo también una idea de tradición étnica. ${ }^{47}$ Tal concepto puede considerarse

46. Según Cécile Gouy-Gilbert, el músico que tocaba el tambor y la flauta recibía el nombre de tampaleo y representaba el diálogo entre bailarines y músicos. Cfr. Gouy-Gilbert, op. cit., pp. I85-186.

47. En los años en que se escribió el reportaje, la pascola y la danza del venado eran bailes típicos de los indios yaquis y mayos. Se celebraban en ocasión de un funeral o de una fiesta religiosa. La danza que le tocó observar a Ortega y que fotografió Ismael Casasola fue una pascola entre los mayos, donde, a diferencia de la del venado, el danzante no porta una cabeza disecada de este animal, sino una máscara de madera tallada con mechones de cerdas que cuelgan. Hoy día, al parecer, entre los yaquis, las máscaras de pascola representan a diferentes animales, como el 

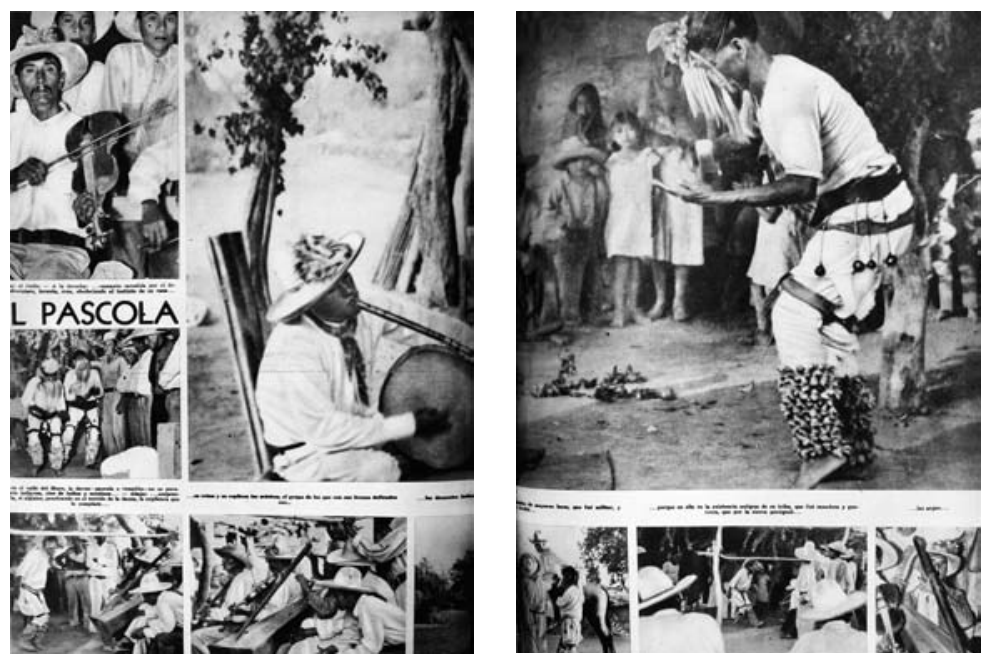

3. Gregorio Ortega, “¡Vamos a ver al Pascola!”, Hoy, vol. X, año 2, núm. I 30, I9 de agosto de I939, s.p. Foto: Ismael Casasola. Hemeroteca Nacional, unAm.

cierto tipo de "discurso histórico" (visión etnográfica que varía con el tiempo), susceptible de un análisis historiográfico. ¿Se constituye de manera diferente el relato de la pascola y la enumeración de personajes a través del tiempo? ¿Es posible detectar variaciones en la práctica y en su descripción a través de un periodo determinado? ¿Qué lugar ocuparon las danzas populares e indígenas en los imaginarios sociales nacionalistas, de construcción de "lo mexicano"? ¿Desde dónde se articulan los discursos en torno a la danza, desde una revista de divulgación o desde una científica? ¿Quiénes narran las prácticas culturales? ¿Cuál es el tono de la narrativa? Éstas son apenas algunas de las preguntas que podemos plantear frente a los textos y las imágenes en esta primera parada.

perro, el lenguón y el chivato, y la de este último es la más común. Como constante iconográfica tenemos los dibujos o pinturas, en alguna parte de la máscara, de los "animalitos del monte": lagartijas, hormigas, ciempiés y alacranes. Cfr. María Eugenia Olavarría, Cruces, flores y serpientes. Simbolismo y vida ritual yaquis, México, Universidad Autónoma Metropolitana-Iztapalapa/Plaza y Valdez, 2003, p. 223. Véase una discusión más amplia de las artes pascola en Spicer, op. cit., I954, pp. I83-I84, y otra realizada con mayor detenimiento en Edward Spicer, Los yaquis. Historia de una cultura, Stella Mastrangelo (trad.), México, Universidad Nacional Autónoma de MéxicoInstituto de Investigaciones Históricas, 1994. 


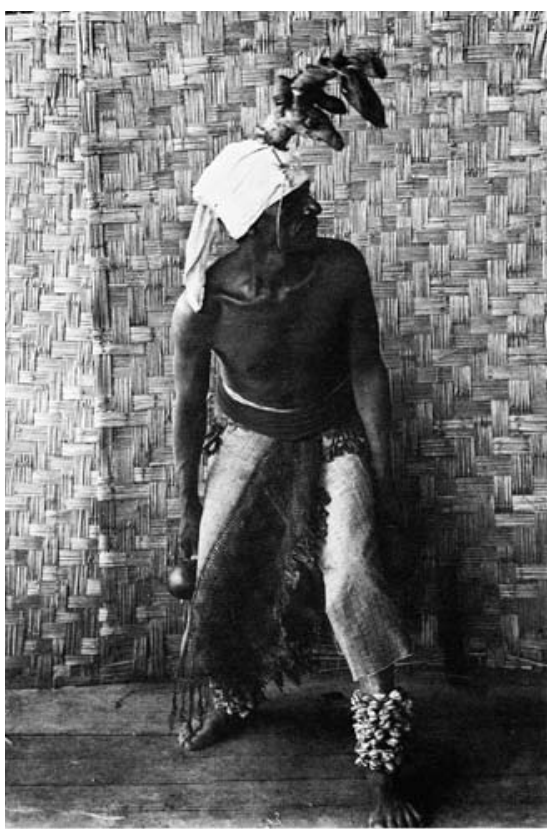

4. Danzante de la "Danza del venado", imagen tomada de León Diguet, $o p$. cit. (infra n. 68), pp. 74-77.

Desde la perspectiva etnográfica, las narraciones escritas de la danza indican que el bailarín va desnudo de la cintura para arriba. ${ }^{48}$ Ésta es la imagen del danzante que capturan las fotografías de León Diguet en el siglo XIX, la que esculpe la conocida ceriescultora de la época Carmen C. de Antúnez y la que ilustra una monografía sobre los yaquis de 1957 (figs. 4 y 5).49 $\operatorname{Sin}$ embargo, no es la imagen que nos ofrecen las fotografías de Ismael Casasola para este reportaje, ya que los dos danzantes que apreciamos portan camisas blancas. Este dato que aparece en la imagen fotográfica puede ser usado por los etnólogos para inquirir sobre los cambios en los usos y costumbres.

El estereotipo del macho "grande y fuerte" subyace en la conformación de la figura del hombre yaqui a lo largo del reportaje. Los recursos que Ortega

48. Carlos Basauri indicaba que "los danzantes son hombres, los que se desnudan hasta la cintura, llevan el calzón remangado hasta la rodilla y adornan esta última prenda, así como sus fajas, con sonajas y listones de vivos colores”. Basauri, op. cit., p. 228 (las cursivas son mías). Lo mismo afirma Spicer.

49. Etnografía de México. Sintesis monográficas, México, Universidad Nacional Autónoma de México-Instituto de Investigaciones Sociales, 1957, p. I63 (monografía sobre los yaquis). 


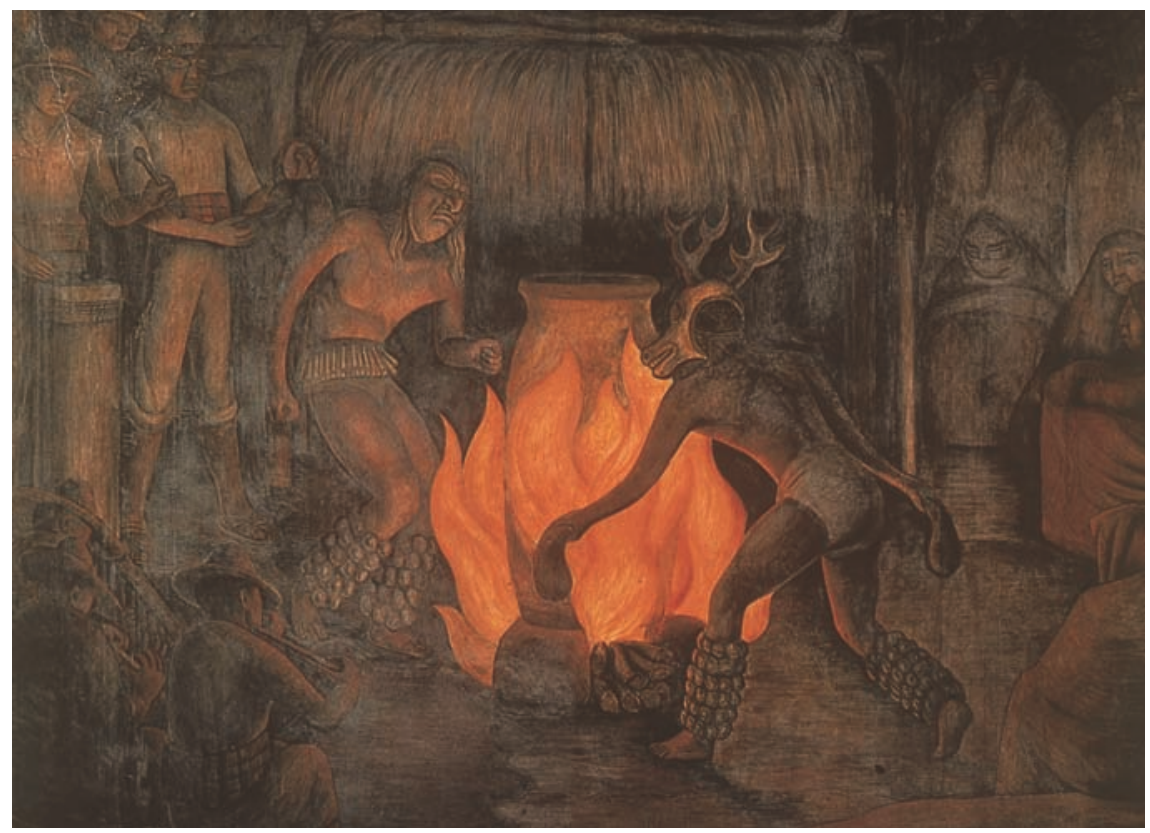

5. Diego Rivera, La danza del venado, ca. I923, fresco, Patio de las Fiestas, Secretaría de Educación Pública. Foto: Archivo Fotográfico IIE-unam. D.R. (C) 2009. Banco de México, "fiduciario" en el Fideicomiso relativo a los museos Diego Rivera y Frida Kahlo. Av. Cinco de Mayo núm. 2, Col. Centro, Del. Cuauhtémoc 06059, México, D. F.

utiliza comprenden tanto la descripción física de los "personajes" como el empleo de rasgos de carácter que denotan virilidad. El ejemplo más claro es la enumeración que hace el reportero de las cuatro mujeres que ya habían sido pareja de Epifanio "a sus cuarenta años". ${ }^{50}$ La primera, Juanita, como "Adelita" prototípica, lo acompañó a pelear con Obregón en la gesta revolucionaria. Evocar la participación de Epifanio en la lucha armada es

50. Dentro del imaginario indigenista de la época y el que se gesta desde el siglo XIX, los indios del norte del país se concibieron y construyeron, debido a su nomadismo, como feroces, salvajes, valientes y polígamos. Véanse por ejemplo Claudio Linati, Trajes civiles, militares y religiosos de México, I828, Justino Fernández (introd., est. y trad.), Manuel Toussaint (pról.), México, Universidad Nacional Autónoma de México, 1956, y Antonio García Cubas, The Republic of Mexico in I876. A Political and Ethnographical Division of the Population, Character, Habits, Costumes and Vocations of its Inhabitants, México, La Enseñanza, I876. 
DOI: http://dx.doi.org/10.22201/iie.18703062e.2009.94.2286

una forma de introducir en el relato la mítica valentía de los hombres que hicieron la Revolución, lo cual permite al lector atribuir al danzante cierto heroísmo. Habrá que recordar lo que no se recuerda en el texto: el levantamiento de Cajeme, entre I875 y I90I, que dio inicio a la guerra del yaqui, durante la cual este grupo fue sistemáticamente perseguido por el ejército porfirista hasta que se escribió una de las notas más negras de la historia del Porfiriato: la deportación masiva de indios yaquis y pápagos hacia Yucatán, ${ }^{\text {I }}$ así como la de 1500 yaquis a México en 1917 y su posterior envío a las Islas Marías, acción promovida por Calles. ${ }^{52}$ También debemos tener presente que Obregón traicionó a los yaquis en $1926 .{ }^{53}$ Resulta curioso que, a once años de uno de los peores desalojos de los indios yaquis de sus tierras, se omita en el artículo reflexión alguna sobre tal acontecimiento. ${ }^{54}$ Esto puede deberse, sin embargo, al acuerdo presidencial firmado por Lázaro Cárdenas en 1937, donde se reglamentaba una región yaqui específica dentro del reparto agra-

5I. Véase Hernández Silva, op. cit., pp. I33-I45.

52. Álvaro Matute, Historia de la Revolución mexicana, I9I7-1924. Las dificultades del nuevo Estado, México, El Colegio de México, I995, pp. 84-85. Como explica Matute, incluso pese a la deportación, pudo más la influenza para diezmar a los yaquis, como ocurrió en el resto del país, que los esfuerzos por controlar el "problema”. Roberto Pesquera sintetizó, según Matute, el sentir de los sonorenses frente a la cuestión yaqui: "asignarles una zona o exterminarlos". Al problema con los yaquis, por lo que respecta a la discriminación e intolerancia étnicas en Sonora, se sumó por supuesto la persecución de los chinos; véanse pp. 86-87.

53. Etnografía de México, op. cit., p. I52. El texto de 1957 tampoco lo consigna y se expresa de este modo sobre su papel durante la Revolución: "Los yaquis y sus hermanos los mayos ganan lauros para su jefe y amigo el general Álvaro Obregón, quien alcanza para ellos las conquistas sociales y económicas de que ahora gozan". Las omisiones en la historia de persecución son muy reveladoras en cuanto al silenciamiento selectivo de la información. Otro error notable, que puede apreciarse después de leer el texto de Gouy-Gilbert, se vincula con la participación de los indios yaquis en la gesta revolucionaria. Ésta aparentemente no es más que una falacia histórica, o por lo menos una exageración que precisa de matices. Se infiere de ese texto que realmente fue Adolfo de la Huerta quien mantuvo de modo más consistente su apoyo a la etnia y recibió protección de ella a modo de escolta en más de una ocasión. Obregón, por otro lado, aparece en este texto como un desalmado traidor. Las complejas relaciones dentro del grupo yaqui, las pugnas entre facciones y sobre todo la persistente defensa de la posesión del territorio y las formas de autogobierno quedan más que claramente plasmadas en sus líneas.

54. Por el contrario, Mary Kay Vaughan ofrece una historia diferente que incluye la diáspora de yaquis hacia Arizona y al cerro del Bacatete, donde fueron bombardeados por el gobierno de Calles a instancias de Obregón. Cfr. Mary Kay Vaughan, La politica cultural en la Revolución. Maestros, campesinos y escuelas en México, 1930-1940, México, Fondo de Cultura Económica, 200I, pp. 252-257. 
rio que, si bien no correspondía al territorio yaqui "tradicional", significaba un primer reconocimiento de las demandas territoriales de esa etnia. A este acuerdo siguió otro de junio de 1939, donde entre otras cosas se aclaraban las soluciones relativas al problema del abasto de agua. Lo que se percibe en el fotorreportaje es una retórica que desecha la información histórica y se concentra en la noticia de ocasión. El cuestionamiento historiográfico nos lleva a pensar que hay un interés en la época, desde la mesa editorial, por hacer que el énfasis de las notas sobre indígenas ofrecidas al público capitalino gire más en torno al folklor, despolitizando las cuestiones sociales y agrarias de los grupos indios. 55

Esta primera parte del artículo que aquí revisamos toma la forma de lo que Rebeca Monroy ha llamado nota gráfica. En ella, una imagen única se usa para condensar el significado de un texto más amplio y funciona así como ilustración representativa e icono de las ideas comunicadas por lo escrito. El resto de la nota es un fotorreportaje, donde las fotografías secuenciales del baile, junto con los pies de foto, relatan e ilustran de manera progresiva el desarrollo de la danza y no se "someten" a los giros que la narración escrita toma. Entonces, lo que se conforma son dos textos paralelos que comparten el material fotográfico aunque lo utilizan y matizan diferenciadamente. Dicho de otro modo, podemos encontrar dos diferentes "puntadas" en la sutura de la imagen fotográfica al texto: una que lo ancla al relato general y otra que lo liga a la nota de pie de foto, aprovechando así, de manera muy productiva, la polisemia de la imagen fotográfica.

En el texto principal, el danzante queda consignado de la siguiente manera:

un pascola que hereda y transmite con fidelidad la música, el vestuario, los pasos, el estilo, el ritual de los bailes y de las fiestas sagradas y que, ramazón sacudida por el delirio dionisiaco, inventa, crea, obedeciendo al instinto de su raza y a una obscura catolicidad fuertemente teñida de idolatría, giros nuevos que apenas creados ya se desvanecieron; pero hacen al pascola, al danzante, venerable a la tribu, amado a las mujeres..$^{56}$

55. Ello se deduce no de esta nota aislada, sino de la revisión hemerográfica más amplia realizada durante mi investigación doctoral. $C f$ r. Deborah Dorotinsky, "La vida de un archivo. 'México indígena' y la fotografía etnográfica de los años cuarenta en México", tesis de doctorado en Historia del Arte, México, Universidad Nacional Autónoma de México-Facultad de Filosofía y Letras, 2003 , cap. 5 .

56. Idem. 
Respetada por su grupo y codiciada por las mujeres, la figura del danzante se traza conforme a un perfil de masculinidad estereotípica. Es curioso que tal "masculinización" de los rasgos culturales, apreciable ya en los años treinta para la cultura dominante, se extiende a la cultura indígena. Se trata de una estrategia de poder, en un sentido foucaultiano del término, con la que se "rescata" a las culturas indígenas de los peligros de la degeneración vista a partir de rasgos considerados "femeninos". Es entonces también una postura de género la que domina este imaginario y una en la cual se debe subrayar la virilidad para valorar positivamente a la cultura yaqui. El pascola es como Zirahuén, el héroe tarasco de la película Janitzio de 1934, encarnado por Emilio, El Indio Fernández: grande, fuerte, respetado por su grupo y con un atractivo sexual que encanta a las mujeres. Sin embargo, a diferencia de Zirahuén, quien reta y cuestiona las tradiciones del grupo al dejar con vida a Eréndira, el danzante yaqui que "hereda y transmite con fidelidad" encierra en sí y porta en su cuerpo las claves, los signos (pasos, vestuario, ritmo) que simbolizan la cultura y vitalidad étnicas. Ésta se expresa además de manera creativa a partir de un estado alterado de conciencia o "dionisiaco", que por otro lado se manifiesta como una parte casi biológica de su ser (obedece al instinto de su raza). En esta nota de divulgación de las prácticas culturales de yaquis y mayos, no extraña encontrar una versión vulgarizada de las ideas nietzscheanas sobre lo dionisiaco como rapto festivo y trance arrebatador. Ortega y los editores no serían los únicos que pensaran en El nacimiento de la tragedia. Diego Rivera parece ya haberlo hecho en los murales del Patio de las Fiestas de la Secretaría de Educación Pública en los años veinte, donde es posible realizar una lectura de opuestos entre los elementos apolíneos del Patio del Trabajo y los dionisiacos del de las Fiestas. Otra característica clave del estereotipo yaqui que se promueve es la del lugar que supuestamente tienen aún las prácticas religiosas prehispánicas. Éste es un punto de referencia casi obligado para subrayar la originalidad de prácticas culturales arraigadas en el pasado fundacional de la identidad: el momento previo a la conquista. Por ello el periodista sostiene que, a pesar de la conversión al catolicismo, los mayos y yaquis no han dejado de lado la idolatría, juicio apropiado para la época y asunto que hoy consideraríamos con mayor relativismo cultural "sincrético" o "pervivencia de prácticas culturales". Apreciamos aquí la diferencia entre el horizonte histórico del pasado (cuando Ortega escribía sus juicios sobre los yaquis y mayos) y el nuestro, en el presente, a no tantos años de distancia del México profundo de Guillermo Bonfil (revaloración del lugar cultural, social, 
histórico y político de los pueblos y las culturas indias) y del levantamiento zapatista de 1994 .

\section{La unidad racial de la tribu}

La segunda parte del artículo comprende una reflexión en torno al grupo yaqui, donde se explicarán los parámetros necesarios para definir a sus integrantes como "broncos y obstinados", capaces de luchar y resistir durante la guerra al grado de que fue la República la que les solicitó la paz a cambio de reconocerles grandes derechos (los acuerdos a los que llegó De la Huerta con los yaquis en los albores del Plan de Agua Prieta). Las fotografías de esta parte del reportaje no son posadas, salvo una de los músicos retratados de frente, y rebosan acción y personajes. En esta parte de la nota el discurso del texto y el de la fotografía se separan y toman direcciones diferentes. Según el texto principal, esa bravura y orgullo se encierran en la "unidad racial de su tribu, sin mirarse en el espejo empañado de los seris". ${ }^{57}$ El discurso enuncia una comparación que no se ve reflejada en las fotografías, ya que el lector no encuentra la fuente visual sobre los indios seris con la cual cotejar las afirmaciones del texto. La comparación interétnica que realiza aquí Ortega nos fuerza a preguntarnos en qué grado en I939 se seguía considerando a la población india una masa completamente indiferenciada. Si bien aún no hay una clara distinción de las etnias, está por formularse en el ámbito de la investigación sistemática. En 1939, desde el Instituto de Investigaciones Sociales de la Universidad Nacional Autónoma de México, su director Lucio Mendieta y Núñez anuncia, en el primer número de la Revista Mexicana de Sociología, la creación del primer archivo fotográfico etnográfico "de todos y cada uno de los grupos indígenas de México". Uno de los propósitos de ese proyecto de inventario étnico era describir los rasgos particulares de cada grupo, entiéndase somáticos, culturales, sociales y fisonómicos, con un peso diferente en cada cual, según los datos disponibles. Debido a la influencia, aún bastante marcada, de la antropología física y la antropometría, aunada a las preocupaciones por elevar el nivel de vida de los indios (desde las vertientes higienistas, eugenistas, educativas y biotipologistas), el interés por las descrip-

57. Hay que recordar que se trata de un texto de divulgación, por lo que el autor no explica esta "unidad racial" como lo hacen los etnólogos cuando hablan de la práctica de la endogamia, que no implica un juicio de valor como el que se manifiesta en la afirmación del reportero. 
ciones físicas (medidas, pigmentación de la piel, patología y fisonomía) siguió predominando en los estudios de carácter académico, por lo que llama mucho la atención ver aparecer descripciones de prácticas culturales como "cápsulas informativas" en las revistas de divulgación.

El alcoholismo y la toxicomanía fueron una preocupación constante de los gobiernos posrevolucionarios y de los científicos sociales, médicos y algunos funcionarios, y por ello no debe sorprendernos que Ortega dedique una parte del artículo a señalar los efectos combinados de música y alcohol entre mayos y yaquis:

en tanto que a los andaluces el alcohol y la música les vuelven clara la alegría, porque canto y danza son una afirmación de que se goza el amor o el dolor, a los yaquis y los mayos el alcohol y la música los tornan sombríos, desesperadamente sombríos, sacándoles de la entraña la angustiosa, rencorosa desconfianza de la tribu..$^{8}$

Así, mediante una descripción caracterizada como un estado anímico "desesperadamente sombrío", el autor teje un tapiz donde el lector capitalino de la revista puede ver aparecer, al lado de las fotografías, una dimensión más "psicológica" de la cultura indígena. Sin embargo, nada que se aprecie como sombrío se ve reflejado en las imágenes, que muestran una progresión del baile hasta llegar a uno de sus momentos más emocionantes cuando el danzante, de espaldas en el suelo, golpea el arpa con los pies para marcar el ritmo de la música. Lo que vemos es el constante ir y venir de los dos bailarines dentro de la enramada, turnándose para que la danza dure lo más posible. También vemos al público que observa muy de cerca, formado por hombres, mujeres y nińos, y a los músicos que, con la gente encima, tocan serios y concentrados. En una o dos imágenes, algún espectador voltea a mirar la cámara. A través de la fotografía documental, la ceremonia se transforma en un espectáculo que el lector de la revista disfruta cómodamente desde su casa.

El momento más desconcertante de la narración ocurre cuando Ortega relata su llegada a la pascola; de pronto ya no nos encontramos junto con él entre los yaquis, como al inicio del artículo, sino que ahora vamos a participar en una danza de la pascola (en una ceremonia de velación) celebrada entre los indios mayos. ¿¿Una confusión por parte del reportero? ¿Reafirmación de que da lo mismo si son unos u otros, pues todos los indios "siguen siendo iguales"? ¿'Indi- 
ca esto acaso la relación interétnica existente entre yaquis y mayos? El reportaje obviamente carece del rigor de un texto académico de esos años, y leído hoy día genera una gran confusión en el lector. ¿Cómo pasamos de los yaquis a los mayos? ¿Por qué describir a un danzante yaqui para luego ir a ver una ceremonia mayo? Si el interés inicial había sido realizar un reportaje entre los yaquis, al presentarse la oportunidad de acudir a un velorio entre los mayos los reporteros no desaprovecharon la ocasión, y la confusión, pues, podría ser meramente circunstancial. De cualquier manera, los estereotipos de bravura indiana, a la que se suma la violencia desatada por el consumo de alcohol, continúan promoviéndose en el texto y tienen su ápex cuando Ortega relata que un militar le advirtió esto: "tan luego como vean los cuchillos, échense a correr y no aleguen. El que alega se muere". Así lo hacen reportero y fotógrafo, temerosos de dejar sus cuerpos como abono a los campos de trigo y ajonjolí.

Parece ser común que Casasola interviniera en aventuras fotográficas donde había que salir corriendo para salvar el pellejo. En 1946, cuando se promovía la primera gran exposición de fotografías de prensa, la revista Mañana empezó a publicar un grupo de "semblanzas" de algunos de estos fotorreporteros. ${ }^{59} \mathrm{La}$ segunda, aparecida el 29 de junio de ese año en el número I48, se dedicó a Ismael Casasola. Estas notas, que se encuentran sin firmar, han sido adjudicadas por la investigadora Rebeca Monroy al lusitano Antonio Rodríguez, crítico de fotografía y de arte. ${ }^{60}$ Lo que el autor de ellas destaca de la personalidad de Ismael Casasola, si bien no analiza las fotografías en sí, es justamente su carácter osado. Con el título de "iAquí están las fotos! Dijo, y se entregó a la policía", ${ }^{61}$ lo que Rodríguez resalta es la valentía de Casasola para conseguir el reportaje gráfico, en este caso las imágenes sangrientas del cadáver de una mesera asesinada por un ferrocarrilero en el antiguo Hotel Motolinía. Pero

59. El director de Mañana era el tabasqueño Regino Hernández Llergo y el jefe de redacción, Luis Alcalde.

6o. Como Rodríguez participó como organizador de la exposición y fue cercano colaborador de los tabasqueños en la revista, no resulta descabellado atribuirle las semblanzas. Incluso, esta falta de firma se debe quizá a una muy acalorada defensa que realiza Antonio Rodríguez de su persona, como crítico literario en este caso, frente a los desmedidamente furiosos ataques que contra él emprendió Salvador Novo, quien lo acusó, entre muchas otras cosas, de ser comunista y protegido del periodista Ortega, y de vivir al amparo de la revista Mañana. Supongo que, para no "meter más leña al fuego", Rodríguez dejó las notas sin firmar. Cfr. Antonio Rodríguez, "Dos respuestas necesarias”, Mañana, núm. I45, 7 de junio de 1946, pp. 24-25.

61. Anónimo, “Aquuí están las fotos! Dijo, y se entregó a la policía”, Mañana, núm. I48, 29 de junio de I946, pp. 37-39, segunda sección, n. 2. 
la escena del crimen se encontraba sellada por la policía y, para poder lograr la nota, Casasola tuvo que violar los sellos. Los mozos del hotel dieron parte a las autoridades y la nota relata una persecución en automóvil que culmina con Casasola entregando los rollos en el periódico y rindiéndose a las autoridades para luego pasar unas horas detenido.

De las tres fotografías incluidas, una a toda plana pertenece a la serie de "El culto al mal en Chichicastenango". ${ }^{62}$ Nos enteramos de lo ocurrido en Guatemala cuando Casasola fue detenido también por la policía junto con el editor de la revista:

Acostumbrado a vencer toda suerte de obstáculos, con tal de cumplir su función informativa, los dos reporteros penetraron en el recinto mismo donde se efectuaban las ceremonias y, contra todas las prohibiciones, tomaron las fotografías que creyeron convenientes.

Salvaron la vida por milagro pero no se libraron de pasar algunas horas en la cárcel. Gracias a una mordida de io dólares (que en todos lados se cuecen habas) lograron readquirir la preciosa información gráfica, decomisada por las autoridades. ${ }^{63}$

¡El editor se jacta de haber escondido los rollos en sus calzones para salvarlos! Rodríguez afirma que es el alto sentido de dignidad, respeto y amor por su profesión lo que caracterizaba a Ismael Casasola, quien entre otras proezas había acompañado a las fuerzas al mando del general Treviño a perseguir a Carranza, tomado parte en la primera expedición formada para negociar y obtener la rendición de Pancho Villa, y asistido con otros fotógrafos al fusilamiento de los implicados en el asesinato de Obregón. El obturador de su cámara, se nos dice, "se había disparado al mismo tiempo que las pistolas y las ametralladoras, anteponiendo su deber al miedo — en medio de episodios de revolución, de zafarranchos políticos, de huelgas". ${ }^{64}$ También se había disparado al son de los tambores y las flautas y al ritmo de los cascabeles del pascola.

Estas imágenes que provienen de las revistas Hoy y Mañana, fotografías en blanco y negro en su mayoría de autores anónimos, contribuyeron, junto con los textos de los artículos y los trabajos etnográficos académicos, a configurar estos entramados simbólicos sobre los grupos indios que habitaban el

62. Ibidem, p. 39.

63. Ibidem, p. 38.

64. Idem. 
6. Fermín Revueltas, Danza del venado,

I933, óleo sobre tela, $54 \times 54.5 \mathrm{~cm}$,

Colección Andrés Blaisten.

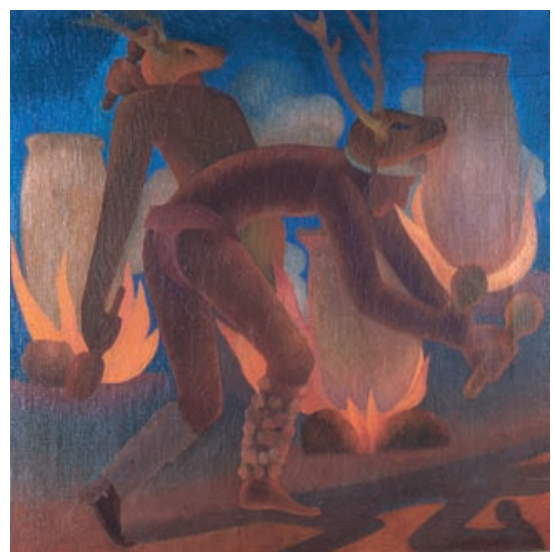

territorio nacional. Sin embargo, en la construcción de "lo indio", las imágenes de las revistas fueron sólo una parte del tejido: la que, desde la perspectiva de la modernidad y las prácticas fotográficas modernistas, representó una paradoja respecto a la construcción cientificista de la antropología, la etnografía y la sociología, donde las fotografías antropométricas decimonónicas mantuvieron un lugar preponderante hasta los años cincuenta. ${ }^{65}$

Habrá que agregar a este repertorio fotográfico el gestado en la pintura y la gráfica que también contribuyó a figurar y construir este imaginario social, ya desde los muros, como La danza del venado (1925), ${ }^{66}$ de Diego Rivera, situada en el muro sur del primer nivel del Patio de las Fiestas, y dos de las grisallas del tercer piso de la Secretaría de Educación Pública (SEP), ${ }^{67}$ o la obra de caballete de artistas como Fermín Revueltas, cual su Danza del venado (1933; figs. 5

65. Cfr. Dorotinsky, op. cit.

66. Rivera relata en 1925 que originalmente el Patio de las Fiestas de la Secretaría de Educación Pública iba a ser pintado por Jean Charlot, Amado de la Cueva y Xavier Guerrero, pero que fue él finalmente quien terminó por ejecutar los frescos. En 1925 había realizado la fiesta titulada La sandunga. Danza galante tehuana y la fiesta fúnebre Danza mortuoria yaqui. Diego Rivera, "Los patios de la Secretaría de Educación Pública", en Xavier Moyssén (comp.), Diego Rivera. Textos de arte, México, Universidad Nacional Autónoma de México-Instituto de Investigaciones Estéticas, 1986, pp. 84-88.

67. Luis Cardoza y Aragón (presentación y notas), Diego Rivera. Los frescos en la Secretaría de Educación, México, Secretaría de Educación Pública/Dirección General de Publicaciones y Bibliotecas, I980. Respecto a los murales, véanse las páginas 36 y I 20. 
y 6) ${ }^{68} \mathrm{~A}$ diferencia de las fotografías de Casasola, donde no aparece el cuerpo del difunto por ninguna parte, el fresco de Rivera incluye en el segundo plano una figura yaciente, probablemente de madera, que toma el lugar del occiso en la velación, en cuyo fondo se distingue un cerro prominente. En el fresco de la SEP también podemos observar la máscara del pascola — que apenas se aprecia en las fotografías de Casasola, ya que el bailarín la porta en un lado del rostro- así como el tocado de cabeza de venado de la danza del mismo nombre. Rivera sintetizó dos danzas dentro de la misma escena, la del venado y la de la pascola. A diferencia de la escena en blanco y negro de la fotografía de Casasola, el fresco de Rivera nos sorprende por la luminosidad y la sensación de atmósfera mística creada por el naranja del fuego alrededor del cual danzan los bailarines; todo está bañado por esta incandescencia como si se tratara de una visión alucinada. El colorido, sin embargo, responde a un sentido de relación cromática con el mural pintado a la derecha, La fundición, y como éste y aquél se encuentran en un muro que recibe poca luz natural, resulta casi lógico que se ilumine mediante estos colores incandescentes. Además, La danza del venado se encuentra en un intersticio situado entre el Patio del Trabajo y el de las Fiestas, y en cierto modo este espacio dedicado a los muertos funciona como transición entre uno y otro topo. Rivera también ha puesto en acto los conceptos clásicos de unidad de acción, pues no pierde el tiempo con detalles que distraen para así condensar en el menor número posible de figuras el mayor contenido simbólico. Aquí tampoco encontramos la manifestación tradicional del atuendo consistente en la cobija amarrada en las piernas, pero sí a dos flautistas, un arpista, dos tamborileros y a los espectadores. Lo que estas representaciones pictóricas de la pascola o el venadito sugieren es lo que narra uno de los pies de foto del fotorreportaje de la revista Hoy: que en la danza ven los yaquis "la existencia antigua de su tribu, que fue cazadora y guerrera, que por la tierra persiguió [...] las arpas”. La finalidad de esta conclusión poética es, por un lado, enaltecer las tradiciones populares tan preciadas en el discurso sobre "lo mexicano" y, por otro, poner de relieve la nostalgia experimentada al apreciar dichas prácticas culturales, que se creían próximas a desaparecer cuando el indio se incorporara a la vida nacional.

68. Podríamos incluso hacer un trabajo "fotográfico-genealógico" e incluir las versiones del danzante creadas desde el siglo XIX, a partir de las fotografías de León Diguet. Véanse por ejemplo Fotografías del Nayar y de California, I893-1900, México, Centre d'Études Mexicaines et Centraméricaines/Instituto Nacional Indigenista, I99I; danzante de la "Danza del venado", pp. 74-77. 
7. Luis Márquez Romay, sin título. Archivo

Fotográfico IIE-UnAM. Colección Luis Márquez Romay, cat. núm. o8.760340.

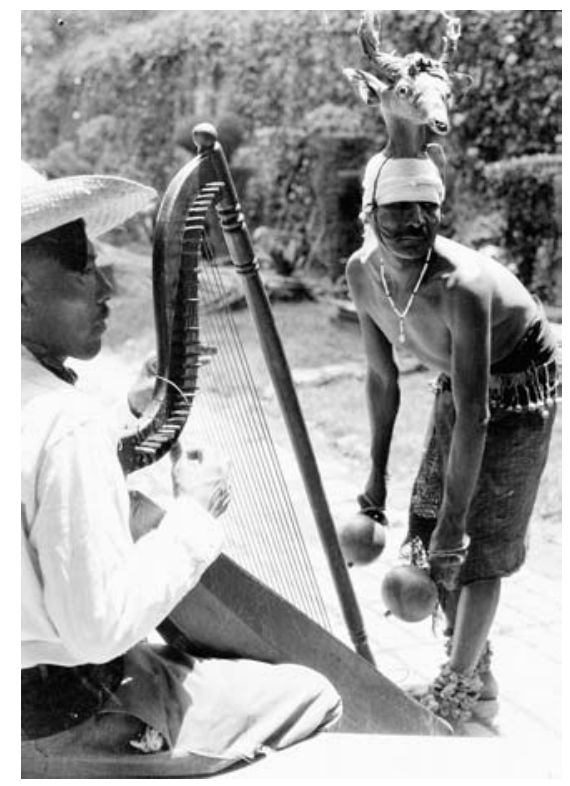

El lugar del folklor en el imaginario indigenista de la primera mitad del siglo xx se debió al rescate de las tradiciones populares que intentaron hacer los ideólogos del renacimiento cultural: artistas, educadores, antropólogos, arqueólogos y escritores, que vieron en las tradiciones la faceta que dotaba de autenticidad y originalidad a "lo mexicano" frente a una modernidad que seguía patrones estadounidenses. Las danzas recibieron un espacio privilegiado, al igual que las artesanías, porque eran vistosas, reproducibles y podían "transportarse" para representar a México en el extranjero. Desde el comienzo de la década de 1920, Rubén M. Campos impulsó algunas manifestaciones de ballet mexicano con tema anticuario: Sacnité (reconstrucción de la supuesta vida cotidiana de los antiguos mayas) y Tlahuicole (sobre la vida de ese héroe tlaxcalteca), por citar algunas. Por otro lado, en ellas se empleaba una mezcla de música nativa y primitiva, con otra monódica o polifónica. ${ }^{69}$ Cuando se estrenó el patio del edificio de la Secretaría de Educación Pública en 1923, se presentó el ballet Quetzalcoatl, cuyo libreto fue escrito por Campos y cuya música se inspiraba en la que se tenía por indígena antigua. Pero ésos fueron

69. Alberto Dallal, La danza en México en el siglo XX, México, Consejo Nacional para la Cultura y las Artes, I994, p. 62. 
apenas los primeros pasos del movimiento de danza mexicanista que, al igual que la plástica y en ocasiones la literatura del periodo, abordó temas, historias, ritmos y a veces formas que pondrían de relieve el carácter nacional y nacionalista del arte conscientemente mexicano. Un ejemplo clásico de ello lo constituye la noche mexicana que Adolfo Best Maugard organizó en el Bosque de Chapultepec con base en danzas regionales de temática indigenista, representadas en espacios decorados con motivos de las artes populares. ${ }^{70} \mathrm{Al}$ crearse las misiones culturales, algunos maestros de danza, como Marcelo Torreblanca, Luis Felipe Obregón, Humberto Herrera y El Chato Acosta, recabaron material dancístico regional que posteriormente interpretaron e incorporaron a representaciones ofrecidas en la capital. La culminación de estos esfuerzos fue quizá el gran festival de danza folklórica organizado para inaugurar el Estadio Nacional en 1924. Los repertorios de danza indígena no se desecharon en los años treinta, como lo prueba una carta sin fecha de Carlos Chávez, donde señala la necesidad de crear una Escuela Mexicana de Danza:

La organización de bailables públicos es importantísima como un medio de lograr las grandes recreaciones populares que condensen las expresiones propias de nuestro País [...]

De las diez plazas de profesores de danza con $\$ 82.00$ al mes, [...] las ocho restantes se aplicarían al nombramiento de ocho danzas indígenas que se elegirían con cuidado en diferentes regiones del país.

El hecho de tener a estos ocho indígenas dentro de nuestra organización de danza, es por mil conceptos importante y casi me parece inútil insistir en la necesidad de hacerlo. ${ }^{71}$

Sin embargo, a pesar de que en 1932 se estableció la primera escuela oficial de danza, dependiente del Departamento de Bellas Artes de la SEP, no se inves-

70. Idem. Dallal señala, además, la importancia de la fundación del Teatro Mexicano del Murciélago, que se convirtió en "semillero de manifestaciones dancísticas mexicanas".

7I. Carta mecanografiada de Carlos Chávez en Archivo Histórico de la Secretaría de Educación Pública, Fondo SEP, Sección Departamento de Bellas Artes, Serie Escuela de Danza, exp. Escuela de Danza, ańo I932. Todo lo relacionado con su establecimiento y funcionamiento, en ff. VII/20I. I/ I. Este material forma parte del rescatado por el equipo de investigación Arte y educación de alumnos de la Facultad de Filosofía y Letras de la unam y del doctor Renato González Mello, del Instituto de Investigaciones Estéticas, proyecto en el que actualmente colaboro. Véase Rosalía Ruiz Santoyo, “1932-1935. La escuela de danza en México y el método Dalcroze", tesis de licenciatura en Historia, México, Universidad Nacional Autónoma de México-Facultad de Filosofía y Letras, 2006. 

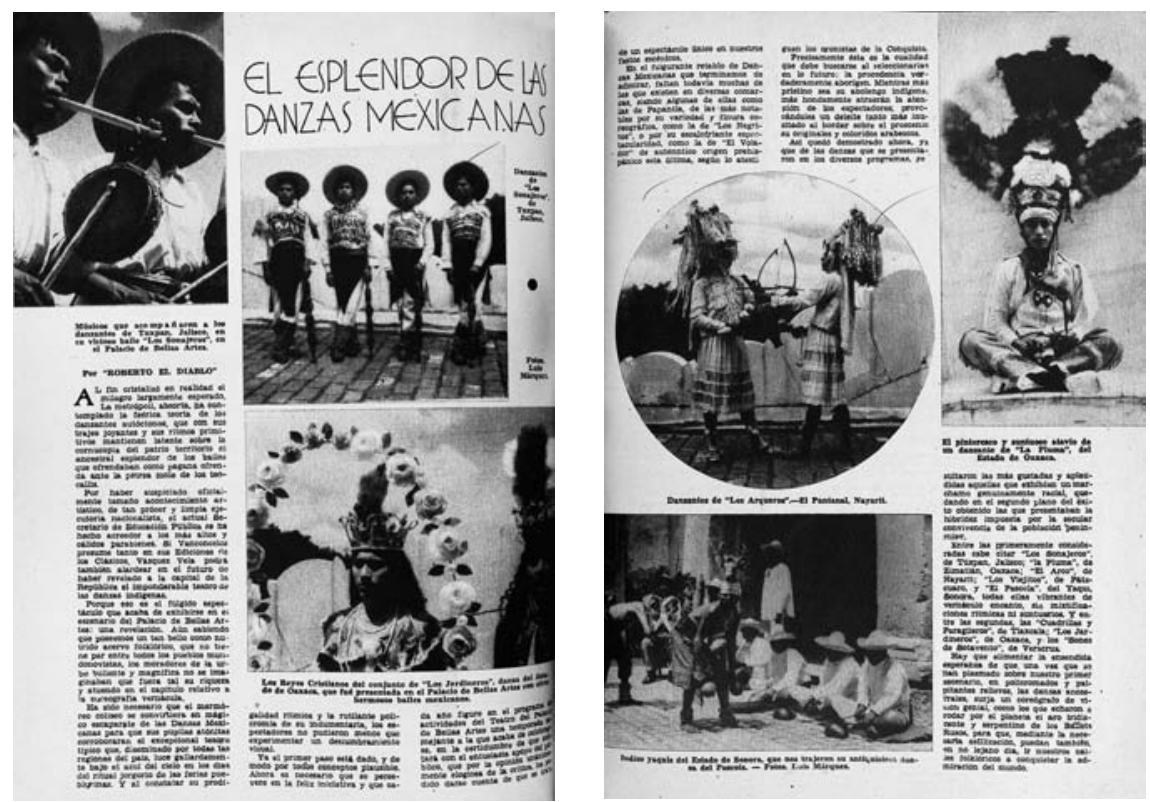

8. Fotografías de Luis Márquez Romay, Revista de Revistas, I de octubre de 1939, s. p.

Hemeroteca Nacional, UNAM.

tigaron, recopilaron, reconstruyeron ni recrearon de manera sistemática las danzas indígenas entonces practicadas. Las danzas de la pascola y el venadito, como expresiones artístico-religiosas de los grupos yaqui y mayo, no pasaron inadvertidas y ocuparon un nicho en los imaginarios sociales indigenistas. Lo mismo ocurrió con los repertorios de danza folklórica ofrecidos tanto a nacionales como a extranjeros, presentados fuera del contexto religioso, social y cultural indígena y, las más de las veces, trastocados por las nuevas corrientes dancísticas modernas, más bien con el afán — como afirma Alberto Dallal— de hacer uso del "espíritu" de las danzas antiguas o ejecutadas por los indígenas. La aspiración de incorporar maestros indios en la Escuela Nacional de Danza parece haberse quedado sólo en anhelo. Las fotografías tomadas por Ismael Casasola para esta nota, como para otras con que también pretendía documentar prácticas culturales indias, forman parte de los contados vestigios que quedan - fuentes históricas primarias—, tanto de la práctica cultural registrada como del acto de fotografiar lo ajeno, atesorarlo y finalmente divulgarlo. Se marca pues la capacidad recreativa de estos imaginarios para una clase media urbana. 
Al trabajar con acervos fotográficos, o incluso con artículos aislados cuando se realiza investigación hemerográfica, los investigadores nos enfrentamos con imágenes que, a decir de Olivier Debroise, generalmente han perdido su referente inmediato, lo que a veces las vuelve anecdóticas, e incluso incomprensibles. En otras ocasiones, como en el caso de las revistas ilustradas, trabajamos con materiales que fueron rechazados en su momento por su "falta de calidad", pero en el nuestro adquieren una especie de "pátina" (casi se antoja decir aura) que las convierte en expresiones de cierto momento, partes fundamentales de la cultura visual y los modos de ver de un periodo. Estas imágenes, que contienen y a la vez construyen significados sociales y culturales, además de las obras de arte, nos permiten reconstruir cierta visualidad pasada. ${ }^{72}$ La historia del arte ha ampliado sus horizontes hasta incluir las fotografías de la prensa ilustrada, que antes rechazó por su falta de calidad o prolijidad, como herramientas para comprender mejor los diferentes modos de ver de una época. En nuestro país, este giro hacia la cultura visual se ha producido sin crear un quiebre dentro de la disciplina, como sí ocurrió en Estados Unidos, donde se abrieron departamentos de estudios visuales y cultura visual para marcar el tránsito a un trabajo interdisciplinario y transdisciplinario. Pero no ha sido un proyecto de ampliación que discurra suavemente. El reto de investigar los "modos de ver" de épocas pasadas supone un intenso trabajo transdisciplinario donde la antropología, la semiótica, la crítica literaria, la historia y la historiografía, la historia del arte y de las ciencias y la cultura visual colaboran cada una con lo suyo para entender los procesos históricos de significación y las maneras en que le conferimos sentido al pasado.

Por último, hay que recalcar que el trabajo historiográfico no consiste en debatir si la imagen en sí contiene o no un discurso histórico, sino en proponerse un análisis de los discursos generados por las imágenes, entendiendo que, cada vez que usamos una imagen con el fin de "escribir Historia" (o escribir historias para comprender por qué atribuimos a las imágenes tales o cuales significados), los documentos fotográficos "reviven" porque seguimos consultándolos. En parte, la tarea crítica que enfrenta esta nueva forma de hacer historia de las imágenes, y también Historia del Arte, equivale a rescatar los sentidos que el investigador impone a las imágenes en cada nueva historia que escribe con base en la interpretación de las imágenes fotográficas. \$̊

72. Cfr. Keith Moxey, "Nostalgia de lo real. La problemática relación de la historia del arte con los estudios visuales", en Moxey, Teoría, práctica y persuasión. Estudios sobre historia del arte, Barcelona, Del Serbal (Cultura artística), 2004, pp. I23-I35. 